\title{
Güzel Sanatlar ve Tasarım Fakültesi Öğrencilerinin "Tasarım" Kavramına Yönelik Metaforları
}

\author{
The Faculty of Fine Arts and Design Students' Metaphors on the Concept of \\ "Design"
}

\section{Cihan Canbolat}

Arș. Gör. Dr., Kastamonu Üniversitesi, Güzel Sanatlar ve Tasarım Fakültesi, Grafik Tasarımı Bölümü email: cihancanbolat@kastamonu.edu.tr (DORCID ID: https://orcid.org/0000-0003-1837-0651

\begin{abstract}
$\checkmark$ iThenticate“ ${ }_{\text {for Autrors \& nesearchers }}$ Bu makale bilimsel etik ve kurallara uygun hazırlanmış ve intihal incelemesinden geçirilmiştir. 25/03/2021 tarihli ve 89 sayılı Kastamonu Üniversitesi Sosyal ve Beşeri Bilimler Araştırma ve Yayın Etiği Kurulu onayı alınmıştır.
\end{abstract}

Atıf (APA 7)/Tocitethisarticle

Canbolat, C. (2021). Güzel sanatlar ve tasarım fakültesi öğrencilerinin “tasarım” kavramına yönelik metaforları. Atatürk Üniversitesi Güzel Sanatlar Enstitüsü Dergisi, 27(47), 329-337. https://doi.org/10.35247/ataunigsed.930294

Makale Gönderim Tarihi/Received: 30/04/2021

Makale Kabul Tarihi/Accepted: 25/09/2021

Makale Yayın Tarihi/Published: 28/10/202

Research Article / Araștırma Makalesi

Öz

Bu araştırma; Güzel Sanatlar ve Tasarım Fakültesi öğrencilerinin "tasarım" kavramına ilişkin sahip oldukları zihinsel imgeleri ortaya çkarmak amacıyla gerçeklestirilmiștir. Araștırmaya Kastamonu Üniversitesi Güzel Sanatlar ve Tasarım Fakültesi Geleneksel Türk Sanatları, Grafik Tasarımı, Resim ve SeramikCam Bölümlerinde öğrenim gören 195 öğrenci katılmıștır. Veriler öğrencilerin, "Tasarım.....................gibidir, çünkü....................gibidir" cümlesini tamamlamalarıyla veriler elde edilmiştir. Araştırmada nitel araştırma yöntemlerinden olgubilim deseni, verilerin değerlendirilmesinde ise içerik analizi modeli kullanılmıștır. Calıșma sonunda tasarım ile ilgili olarak toplam 98 metafor üretmiştir. Öğrencilerin tasarım kavramına yönelik gelistirdiği metaforlar; alan/tür olarak tasarım, amaç olarak tasarım, bilişsel süreçler olarak tasarım, duyuşsal süreçler olarak tasarım, bilişsel ve duyuşsal süreçler olarak tasarım, doğa olarak tasarım, insana özgü olarak tasarım, iz olarak tasarım, kültür olarak tasarım, obje olarak tasarım, ölçüt olarak tasarım, özgürlük olarak tasarım, sanat olarak tasarım, yaratıcılık olarak tasarım, yaşam olarak tasarım, yer/mekân olarak tasarım, zaman olarak tasarım olmak üzere 17 kategori altında toplanmıștır. Ayrıca araștırma sonucunda öğrencilerin tasarım kavramına yönelik ürettiği metaforların bölümlere göre farklılık gösterdiği tespit edilmiştir.

Anahtar kelimeler: Güzel Sanatlar, Tasarım, Metafor, Zihinsel İmge

\begin{abstract}
This research was carried out to reveal the mental images of the students of the Faculty of Fine Arts and Design regarding the concept of "design". 195 students studying at Kastamonu University Faculty of Fine Arts and Design, Traditional Turkish Arts, Graphic Design, Painting, and Ceramics-Glass Departments participated in the study. The data were obtained when the students completed the sentence "Design is like ................... because it is like ................... In the study, phenomenological design, one of the qualitative research methods, was used, and the content analysis model was used in the evaluation of the data. At the end of the study, he produced a total of 98 metaphors regarding design. The metaphors students developed for the concept of design; design as field/genre, design as purpose, design as cognitive processes, design as affective processes, design as cognitive and affective processes, design as nature, design as human, design as trace, design as culture, design as an object, criterion design, design as freedom, design as art, design as creativity, design as life, design as place/space, and design as time. In addition, as a result of the research, it was determined that the metaphors produced by the students for the concept of design differ according to the departments.
\end{abstract}

Keywords: Fine Arts, Design, Metaphor, Mental Image

\section{Giriş}

Gelişen ve değişen dünya ile birlikte tasarımı insan yaşantısının her noktasında görmek mümkündür. Tasarım alanının genişlemesi ile beraber anlamının da genişlediği söylenebilir. Tasarım sözlük tanımıyla "Zihinde canlandırılan biçim, tasavvur", ya da "Bir sanat eserinin, yapının veya teknik ürünün ilk taslağı, tasar, çizim, dizayn” dır (TDK, t.y). Çevik (2011)'e göre tasarım “Zihinde tasarımlanan şekil, tasavvur etmektir” (s. 101). Çaydere (2016) tasarım kavramını, insanın ihtiyaçlarından ortaya çıkan problemleri çözmeye yönelik kullanılan ve plastik sanatlardan endüstri alanına kadar disiplinler arası yapılan tüm çalışmaları kapsar, şeklinde tanımlamıştır. Becer (2009) ise tasarım kavramını "oluşturulacak yapının organizasyonu ile ilgili her türlü faaliyet" olarak tanımlarken tasarımı, bir yapıya ve bu yapıyı planlamaya benzetir (s. 32). Tasarımın pek çok tanımı yapılabilir. Ancak "tasarım nedir?" sorusu yerine bu kavramın ne olduğu, neye benzediği veya neyi gösterdiğine ilişkin cevaplar, tasarım kavramını anlamaya katkı sağlar. Tasarımı bu yönüyle anlamanın en iyi yolu metafor kullanmakla mümkün olabilir.

Türkçe kelime anlamı mecaz, istiare olarak bilinen metaforun oluşumunda bir kavram başka bir kavram yerine benzetme yoluyla kullanılır. Metafor, birbirine benzemeyen iki ifade ya da olgu arasında ilişki kurarak belirli bir zihinsel şemayı başka bir zihinsel şemaya yansıtmaya olanak sağlamaktadır (Tanrıverdi ve Kahraman, 2019, s. 277-278). Metafor, bir obje veya bir olgunun temel özelliklerini ortaya koymaya yönelik kullanılan bir araçtır. 
Metafor geliştirmek ve üretmek hem analiz eden kişi hem de okuyucu için eğlenceli olmakla beraber güçlü bir metafor tek başına birçok anlam taşır. Bu yönüyle metafor bulguları güçlü ve etkili bir biçimde iletmenin yoludur (Patton, 2018, s. 505). Metafor, bireyin yaşantı ve deneyimlerine anlam kazandırması, doğayı ve çevreyi anlaması, nesnel gerçeklikleri belirli yorumlarla ortaya çıkarmasına olanak sağlar. Bilim insanları dünyayı anlamada ve açıklamada kuramsal bilgileri ve analitik araçları geliştirirken metafor kullanır (Yıldırım ve Şimşek, 2018, s. 206). Birçok sanatçı, eğitimci veya düşünür tasarım kavramını tanımlamak için metaforlardan yararlanmıştır. Tasarımın ne olduğu ve neye benzediği ile ilgili olarak öğrencilerin geliştirdikleri metaforlar ile bugüne dek sanatçılar, eğitimciler veya düşünürler tarafından geliştirilmiş metaforlar arasında benzerlik ya da farklılıkların tespiti bakımından bu araştırma önemli olacaktır. Metaforlar bilinmeyen bir şeyin öğretilmesi ve öğrenilen bilgilerin aktarılması ve hatırlanmasında oldukça önemlidir. Özellikle eğitim alanında kullanılan metaforlar öğrencilere zihinlerinde var olan eski bilgilerin gün yüzüne çıkarılarak ve öğrencilerin sahip oldukları tecrübelerle yeni bilgilerle bağ kurmayı sağlar. Sanat ve tasarım eğitiminin en temel görevlerinden biri de sorgulamaktır ki "tasarım" kavramının metafor yolu ile incelenmesi bireylerin kişiliklerine, yeni bir bakış açısı getirmelerine ve sanatsal üretimlerine yansıması bakımından son derece önem taşır (Uçar ve diğerleri, 2019).

Bu araştırma Güzel Sanatlar alanında eğitim gören öğrencilere yönelik “tasarım” kavramına ilişkin herhangi bir metafor çalışmasının yapılmamış olması sebebiyle ilgili alan yazına katkı sağlayacağı düşünülmektedir. Buradan hareketle bu araştırmanın amacı Güzel Sanatlar ve Tasarım Fakültesinin dört bölümünün farklı sınıf düzeylerindeki öğrencilerin "tasarım” kavramına yönelik geliştirdikleri metaforları tespit etmektir. Bu amaç doğrultusunda aşağıdaki soruları cevap aranmıştır:

1. Güzel Sanatlar ve Tasarım Fakültesi öğrencilerinin "tasarım” kavramına yönelik geliştirdikleri metaforlar ortak özellikleri bakımından hangi kategoriler altında toplanmaktadır?

2. Bu kategoriler bölümlere göre farklılık göstermekte midir?

\section{Yöntem}

\subsection{Araştırmanın Modeli}

Güzel Sanatlar ve Tasarım Fakültesi öğrencilerinin tasarım kavramına yönelik algılarını metafor yoluyla belirlemeyi amaçlayan bu araştırma, nitel araştırma yöntemleri çerçevesinde gerçekleştirilmiştir. Ayrıca araştırmada olgubilim çalışması yapılmıştır. Olgubilim (Phenomenology tamamıyla yabancı olmayan aynı zamanda tam olarak anlamını kavrayamadığımız olguları araştırmak amacıyla bizlere çalışma zemini oluşturur (Yıldırım ve Şimşek, 2018, s. 69).) Farkında olduğumuz ancak derinlemesine ve ayrıntılı bir anlayışa sahip olmadığımız olgulara odaklanır. Bir olguyu daha iyi tanımamıza ve anlamamıza yardımcı olacak örnekler, açılamalar ortaya koyabilir (Büyüköztürk ve diğerleri, 2017, s. 21-22). Bu çalışmada öğrencilerin görüşleri doğrultusunda tasarım kavramına yüklenen anlamlar ayrıntılı bir şekilde incelendiği için olgubilim çalışması kullanılmıştır.

\section{2. Çalışma Grubu}

Araştırmanın çalışma grubunu 2020-2021 öğretim yılında Kastamonu Üniversitesi Güzel Sanatlar ve Tasarım Fakültesi’ne bağlı Geleneksel Türk Sanatları Bölümü, Grafik Tasarım Bölümü, Resim Bölümü ile Seramik ve Cam Bölümü'nde öğrenim gören 195 öğrenci oluşturmaktadır. Araştırmaya katılan öğrencilere ait bilgiler Tablo 1 'de yer almaktadir.

Tablo 1

Araştırmaya Katılan Öğrenciler ve Bölümleri

\begin{tabular}{|c|c|c|c|c|c|}
\hline \multirow{2}{*}{ Bölüm } & \multicolumn{2}{|c|}{ Kadın } & \multicolumn{2}{|c|}{ Erkek } & \multirow{2}{*}{$\begin{array}{c}\text { Toplam } \\
\mathrm{n}\end{array}$} \\
\hline & $\mathrm{n}$ & $\%$ & $\mathrm{n}$ & $\%$ & \\
\hline Geleneksel Türk Sanatları & 28 & 65,1 & 15 & 34,9 & 43 \\
\hline Grafik ve Tasarım & 50 & 69,4 & 22 & 30,6 & 72 \\
\hline Resim & 42 & 82,4 & 9 & 17,6 & 51 \\
\hline Seramik ve Cam & 17 & 58,6 & 12 & 41,4 & 29 \\
\hline Toplam & 137 & 70,3 & 56 & 29,7 & 195 \\
\hline
\end{tabular}

Araştırmaya katılan öğrencilerin \%70,3'ü kadın, \%29,7'si erkek öğrencidir. Çalışma grubu belirlenirken dört farklı bölümden öğrenci seçilmiştir. Bunun sebebi, her bölümün farklı disiplinlerde olması, öğrencilerin lisans eğitimi boyunca aldıkları derslerin farklı olması ve bu doğrultuda farklı tasarım anlayışlarının olmasından kaynaklanmaktadır. Bu durumun öğrencilerin tasarım ile ilgili metaforlarını etkileyeceği düşünülmektedir.

\subsection{Veri Toplama Aracı}

Araştırmaya katılan öğrencilerin "tasarım” kavramına ilişkin geliştirdikleri metaforların belirlenmesinde Saban (2004) tarafından geliştirilen "Öğretmen ........ gibidir; çünkü .........." veya "Öğretmen ............'a benzer; çünkü ............” biçimindeki yarı açık uçlu sorulardan yararlanılmıştır. Bu doğrultuda öğrencilere sayfanın üst 
bölümünde bu ibarenin yer aldığı bir form verilmiştir. Öğrencilerin tasarım ile ilgili düşüncelerini harekete geçirebilmek amacıyla metafor kavramının hangi amaçlarla kullanılabileceği konusunda bilgi verilmiştir. Ayrıca; öğrencilere isterlerse metaforları canlı veya cansız varlıklardan seçebileceklerine ilişkin farklı önerilerde bulunulmuştur. Bir ders saati içerisinde veri toplama aracı olarak kullanılan cümlenin tamamlanması istenmiş ve ders sonunda formlar toplanmıştır.

\subsection{Verilerin Analizi}

Güzel Sanatlar ve Tasarım Fakültesi'nde öğrenimlerine devam eden 195 öğrencinin açık uçlu sorulara vermiş oldukları cevaplar içerik analizine tabi tutulmuştur. Analiz, araştırma sorusuna verilen cevaplardan ortak tutum, duygu, düşünce ortaya konarak sonuca ulaşma yöntemidir. Veriler kendi içinde belli özelliklere göre sınıflandırılır (Baș ve Akturan, 2008, s. 116). İçerik analizinde temel amaç, toplanan verileri açıklayabilecek kavramlara ve ilişkilere ulaşmaktır. İçerik analizi desen, tema ve anlamlar çıkarma çabası içinde verilerin dikkatli, ayrıntılı ve sistematik bir biçimde incelenmesi ve yorumlanmasıdır (Şentuna Akay, 2019, s. 344). Metaforik ifadelerin analiz edilmesi ve yorumlanma süreci sırasıyla adlandırma aşaması, tasnif etme (eleme ve arıtma) aşaması, kategori geliştirme aşaması, geçerlilik ve güvenirliği sağlama aşaması, verilerin sayısallaştırılması aşaması (Saban ve diğerleri, 2006) olarak beş aşamada gerçekleştirilmiştir.

\subsubsection{Adlandırma Aşaması}

$\mathrm{Bu}$ aşamada ilk olarak araştırma sorusu doğrultusunda öğrencilerin geliştirdikleri metaforların her biri ayrı ayrı kodlanarak bir liste oluşturulmuştur. Ardından araştırmanın amacına uygun olarak öğrencilerin oluşturdukları metaforların geçerli olup olmadığı kontrol edilerek uygun olmayanlar çıkarılmıştır.

\subsubsection{Tasnif Etme (Eleme ve Arıtma) Aşaması}

Öğrencilerin geliştirdikleri metaforlar gruplandırılarak benzerlik ve farklılıkları açısından analiz edilmiştir. Öğrencilerin cevaplarında kurulması gereken anlam ilişkisinin bulunamaması ve gerekçe gösterilmemesi sebebiyle 18 adet form geçersiz sayılarak araştırmaya dahil edilmemiştir. Örneğin; "Tasarım hayal bulutu gibidir, çünkü bulutlar tasarımı destekler” (Ö1) şeklindeki ifadeler neyi anlatmak istediği anlaşılmadı̆̆ için kapsam dışı bırakılmıştır. Bir başka öğrencinin, "Tasarım sanat gibidir, çünkü doğadan etkilenir” (Ö26) biçimindeki ifadesi ise metafor ile tasarım arasındaki bağlantı kurulamadığı için değerlendirmeye alınmamıştır. Buna benzer verilen cevaplar değerlendirme dişında tutulduktan sonra toplamda 177 adet metafor elde edilmiştir. Bu metaforlardan benzer olanları gruplandırıldıktan sonra 98 adet geçerli metafor sıralanarak değerlendirilmiştir.

\subsubsection{Kategori Gelişstirme Aşaması}

Öğrenciler tarafından geliştirilen metaforlar "tasarım” kavramına yönelik sahip oldukları ortak özellikler bakımından gruplanmış ve 177 öğrenci tarafından oluşturulan geçerli 98 adet metafor, 17 ayrı kategoride toplanmıştır.

\subsubsection{Geçerlik ve Güvenirlik Aşaması}

Araştırmanın güvenirliğini sağlamak amacıyla araştırmada belirlenen 17 ayrı kategori altında verilen metaforların söz konusu kategori içinde yer alıp almadığını belirlemek için iki uzmanın görüşüne başvurulmuştur. Bu amaçla 98 metaforun alfabetik listesi ve 17 ayrı kategorinin özelliklerini içeren bir liste uzman görüşüne sunulmuştur. Metaforların hiçbiri dışarıda kalmayacak biçimde kategorilere yerleştirilmesi istenmiştir. Bu aşamada uzmanların yaptığı sınıflama karşılaştırılmıştır. Yapılan karşılaştırma sonunda görüş birliği ve görüş ayrılığ1 sayıları tespit edilerek araştırmanın güvenirliği, güvenirlik=görüş birliği/görüş birliği + görüş ayrılığı formülü (Miles ve Huberman, 2019, s.64) kullanılarak hesaplanmıştır. Hesaplama sonucunda kodlayıcılar arasındaki uyumun \%94 olduğu tespit edilmiştir. Veri analizinin güvenilir olabilmesi için bu değerin en az \%70 olması gerekmektedir. İnceleme sonrasında uzmanlar arasında görüş birliğine varılarak veriler düzenlenmiştir.

\subsubsection{Nicel Verilerin Analizi}

Toplam 98 metaforun belirlenmesi ve bu metaforlar doğrultusunda oluşturulan 17 kategorinin geliştirilmesinin ardından bütün veriler SPSS istatistik programına aktarılmıştır. 98 metaforu ve 17 kategoriyi temsil eden öğrenci sayısı (n) ve yüzdesi hesaplanmıştır. Ayrıca bölüm değişkenine göre Kay-Kare $(\chi 2)$ testi yapılmış ve sonuçları analiz edilerek yorumlanmıştır.

\section{Bulgular ve Yorum}

Bu bölümde Güzel Sanatlar ve Tasarım Fakültesi öğrencilerinin “tasarım” kavramına yönelik geliştirdikleri metaforlar ve kategorilere ilişkin bulgular sunulmuştur.

\subsection{Kategorilere İlişkin Bulgular}

Araştırmada elde edilen bulgulara göre, öğrenciler tarafından tasarım kavramı ile ilgili 98 adet geçerli metafor 
üretilmiş ve bu metaforlar 17 kategori altında toplanmıştır. Öğrencilerin geliştirdikleri metaforlar ve bu metaforların ait oldukları kategoriler Tablo 2’de sunulmuştur.

Tablo 2

Metaforların Kategorilere Göre Dă̆ılımı

\begin{tabular}{|c|c|c|c|}
\hline Kategori & Metafor adı & $\mathrm{f}$ & $\%$ \\
\hline 1- Alan/Tür & Bir bilim dalı (1), Felsefe (1), Masal (1), Matematik (1), Şiir (1) & $\begin{array}{l}5 \\
5\end{array}$ & $\begin{array}{l}5,1 \\
2,8\end{array}$ \\
\hline 2-Amaç & Hedefler (1), Proje (1), Yaşam Amacı (2) & $\begin{array}{l}3 \\
4\end{array}$ & $\begin{array}{l}3,0 \\
2,3\end{array}$ \\
\hline 3-Bilişsel Süreçler & Akıl (2), Beyin Fırtınası (1), Düşünce (5), Hayal (24), Zeka (2) & $\begin{array}{c}5 \\
34\end{array}$ & $\begin{array}{c}5,1 \\
19,2\end{array}$ \\
\hline 4-Duyuşsal Süreçler & Aşk (3), Sevgi (2), İçimizdeki Aşk (1), Duygu (2), İçsel güdü (1) & $\begin{array}{l}5 \\
9\end{array}$ & $\begin{array}{l}5,1 \\
5,1\end{array}$ \\
\hline 5-Bilişsel ve Duyuşsal Süreçler & Alg1 (1), Oyun (2), & $\begin{array}{l}2 \\
3\end{array}$ & $\begin{array}{l}2,9 \\
1,7\end{array}$ \\
\hline 6-Doğa & $\begin{array}{l}\text { Ağaç (5), Çamur (1), Çiçek (1), Çarkta dönen su (1), Doğa (2), Deniz (1), Güneş } \\
\text { (1), Gökkuşağı (1), Gökyüzü (1), Işık (2), Işığın Yönü (1), Kuş (2), Okyanus (1), } \\
\text { Parlayan Yıldız (1), Su (1), Toprak (1), Tohum (1), Yıldız (1) }\end{array}$ & $\begin{array}{l}18 \\
25\end{array}$ & $\begin{array}{l}26,4 \\
14,1\end{array}$ \\
\hline 7-İnsana özgü & $\begin{array}{l}\text { Arkadaşlık (1), Bebek (1), Büyümek (1), Beyin (3), Çocuk (1), Görmek (1), Göz } \\
\text { Rengi (1), İhtiyaç (1), İnsan (2), İnsanın Kendi (1), Insanın Aynası (1), Karakter (1), } \\
\text { Ruh (2), Terapi (1), Uyku (1), Yemek (1), Yansıma (1) }\end{array}$ & $\begin{array}{l}18 \\
21\end{array}$ & $\begin{array}{l}26,4 \\
11,9\end{array}$ \\
\hline 8-İz & İmza (2), Parmak İzi (1), Süsleme (1) & $\begin{array}{l}3 \\
4\end{array}$ & $\begin{array}{l}3,0 \\
2,3\end{array}$ \\
\hline 9-Kültür & Kültür (1) & $\begin{array}{l}1 \\
1\end{array}$ & $\begin{array}{l}1,4 \\
0,6\end{array}$ \\
\hline 10-Obje & $\begin{array}{l}\text { Alet (1), Ayna (2), Bozuk Saat (1), Kutu (1), Matruşka (1), Mum (2), Para (1), Şekil } \\
\text { (1) }\end{array}$ & $\begin{array}{c}8 \\
10\end{array}$ & $\begin{array}{c}11,7 \\
5,6\end{array}$ \\
\hline 11-Ölçüt & Kusursuz olmak (1) & $\begin{array}{l}1 \\
1\end{array}$ & $\begin{array}{l}1,4 \\
0,6\end{array}$ \\
\hline 12-Özgürlük & Sınırsızlık (1), Özgürlük (7) & $\begin{array}{l}2 \\
8\end{array}$ & $\begin{array}{l}2,9 \\
4,5\end{array}$ \\
\hline 13-Sanat & Realizm (1), Sanatın iskeleti (1), Güzellik (1), Estetik (2), Uyum (1) & $\begin{array}{l}5 \\
6\end{array}$ & $\begin{array}{l}5,1 \\
3,4\end{array}$ \\
\hline 14-Yaratıcılık & $\begin{array}{l}\text { Einstein (1), El Becerisi (1), Farklılık (1), Güç (1), Kendimize Özgü (2), Kavga (1), } \\
\text { Kalp (1), İcat (1), Teknoloji (3), Yaratıcılık (4), Yenilik (6) }\end{array}$ & $\begin{array}{l}11 \\
22\end{array}$ & $\begin{array}{l}16,1 \\
12,4\end{array}$ \\
\hline 15-Yaşam & Başlangıç (1), Hayat (5), Varoluş (2) & $\begin{array}{l}3 \\
8\end{array}$ & $\begin{array}{l}3,0 \\
4,5\end{array}$ \\
\hline 16-Yer/Mekân & $\begin{array}{l}\text { Bileşen (1), İnşaat (4), Dünya (3), İstanbul (1), Eyfel Kulesi (1), Fabrika (1), Uzay } \\
\text { (1) }\end{array}$ & $\begin{array}{c}7 \\
12\end{array}$ & $\begin{array}{c}10,2 \\
6,8\end{array}$ \\
\hline 17- Zaman & Süreç (1), Zaman (2) & $\begin{array}{l}2 \\
4\end{array}$ & $\begin{array}{l}2,9 \\
2,3\end{array}$ \\
\hline Toplam & & $\begin{array}{c}98 \\
177\end{array}$ & $\begin{array}{l}100 \\
100\end{array}$ \\
\hline
\end{tabular}

Tablo 2'deki verileri şu şekilde özetlemek mümkündür:

Öğrenciler tarafından "tasarım” kavramına yönelik toplam 98 adet metafor üretilmiş ve bu metaforlar 17 başlık altında kategorize edilmiştir. Kategoriler incelendiğinde bilişsel süreç olarak tasarım $(\% 19,2)$, doğa olarak tasarım $(\% 14,1)$, yaratıcılık olarak tasarım $(\% 12,4)$ ve insana özgü olarak tasarım $(\% 11,9)$ kategorilerinin ön plana çıktığ görülmektedir. Metaforların büyük bir bölümü soyut kavramlarla ilişkilendirilmiştir.

\subsubsection{Alan/Tür Olarak Tasarım}

Bu kategoriyi 5 öğrenci $(\% 2,6)$ ve $5(\% 5)$ metafor temsil etmektedir. Alan tür olarak tasarım kategorisi altında bir bilim dalı $(\mathrm{n}=1)$, felsefe $(\mathrm{n}=1)$, masal $(\mathrm{n}=1)$ ve matematik $(\mathrm{n}=1)$ metaforları ön plana çıkmıştır. Öğrenciler bir bilim dalı metaforuna ilişkin “Tasarım bir bilim dalı gibidir, çünkü arayış içindedir (Ö102)”, felsefe metaforuna ilişkin "Tasarım felsefe gibidir, çünkü yorum gerektirir (Ö192)" ve masal metaforuna ilişkin "Tasarım masal gibidir, çünkü sürükleyicidir (Ö193)”, diyerek tasarımın bilim dalı, felsefe ve edebi bir anlatım türü olan masal alanına vurgu yapılmıştır.

\subsubsection{Amaç Olarak Tasarım}

Amaç olarak tasarım kategorisi altında öğrenciler hedefler, proje ve yaşam amacı şeklinde 3 metafor geliştirmişlerdir ve bu kategoriyi 4 öğrenci $(\% 2,3)$ temsil etmektedir. Öğrenciler hedefler metaforuna ilişkin “Tasarım hedef gibidir, çünkü kendimiz planları (Ö172)”, proje metaforuna ilişkin “Tasarım proje gibidir, çünkü planlarız (Ö171)” ifadelerini kullanmışlardır. Bu ifadelerle tasarımın bir amaçla ve belli bir plan, program doğrultusunda yapıldığı vurgulanmaktadır.

\subsubsection{Bilişsel Süreçler Olarak Tasarım}

Bilişsel süreçler olarak tasarım kategorisi altında hayal $(n=24)$ metaforu dikkate değer bir sayıdadır ve hayal 
metaforu üzerinde durulmuştur. Öğrenciler hayal metaforuna ilişkin olarak "Tasarım hayal gibidir, çünkü ucu bucă̆ı yoktur (Ö4)”, “Tasarım hayal gibidir, çünkü soyutlar (Ö5)” ve “Tasarım hayal gibidir, çünkü istediğim her şeyi oraya koyabilirim (Ö32)" şeklinde ifade etmişlerdir. Tasarımın herhangi bir sınırlama olmadan ve zihinde tasarlanan bir süreç olduğu vurgulanmaktadır.

\subsubsection{Duyuşsal Süreçler Olarak Tasarım}

Duyuşsal süreçler olarak tasarım kategorisi altında aşk (3 öğrenci, \%1,7), sevgi (2 öğrenci, \%1,1) ve duygu (2 öğrenci, \%1,1) metaforu üzerinde yoğunlaşılmıştır. Öğrenciler aşk metaforuna ilişkin olarak “Tasarım aşk gibidir, çünkü hayal gücünü zorlar (Ö137)”, sevgi metaforuna ilişkin olarak “Tasarım sevgi gibidir, çünkü dünyayı güzelleştirir (Ö33)” ş̧eklinde ifadelerde bulunmuşlardır. Tasarımın aşk, sevgi gibi duygulara benzetildiği, aşk gibi hayal gücünü zorladığı ve sevgi gibi dünyayı güzelleştirdiği üzerinde durulmuştur.

\subsubsection{Bilişsel ve Duyuşsal Süreçler Olarak Tasarım}

Bilişsel ve duyuşsal süreçler olarak tasarım kategorisi altında oyun (2 öğrenci, \%1,1) metaforu ön plana çıkmaktadır. Bu metafora ilişkin öğrenci “Tasarım oyun gibidir, çünkü deneyerek ortaya çıkar (Ö191)” ifadesiyle tasarımın bilişsel ve duyuşsal özelliğini ortaya koyan oyun metaforu vurgulanmıştır. Tasarımın oyun olarak görülmesi tasarımın deneysel ve eğlence işlevi olması yönüyle ilişkilendirilmiştir.

\subsubsection{Doğa Olarak Tasarım}

Bu kategoride ağaç (5 öğrenci, \%2,9) ve kuş (2 öğrenci, \%1,1) metaforu ön plana çıkmaktadır. Öğrenciler ağaç metaforuna ilişkin "Tasarım ăgaç gibidir, çünkü hep meyve verir (Ö63)”, kuş metaforuna ilişkin "Tasarım kuş gibidir, çünkü uçtukça yeni fikirler ortaya çıkar” ifadelerini kullanmışlardır. Tasarım kavramı doğadaki unsurlarla ilişkilendirilmiştir. Metaforlar gerekçeleriyle incelendiğinde çoğunlukla doğanın verimli, bereketli ve ilham veren yönünün vurgulandığı görülmektedir.

\subsubsection{Insana Özgü Olarak Tasarım}

Bu kategoriyi 21 öğrenci $(\% 11,9)$ ve $18(\% 26,4)$ metafor temsil etmektedir. Bu kategoride ön plana çıkan metaforlar beyin (3 öğrenci, \%1,7), insan (2 öğrenci, \%1,1) ve ruh (2 öğrenci, \%1,1) metaforlarıdır. Öğrenciler bu kategoride insana özgü özellikleri tasarım metaforu ile ilişkilendirmiştir. Bu kategoride yer alan beyin metaforuna ilişkin “Tasarım beyin gibidir, çünkü her şey orada başlar (Ö70)”, insan metaforuna ilişkin “Tasarım insan gibidir, çünkü kişiye göre değişir (Ö59)”, ruh metaforuna ilişkin “Tasarım ruh gibidir, çünkü anlatılmak istenen her şey oradadır" şeklinde ifade etmişlerdir. Bu metaforlarla tasarımın kişiye özgü olduğu, insan gibi farklı olduğu, insan ruhu gibi özel ve gizemli olduğu vurgulanmıştır.

\subsubsection{Iz Olarak Tasarım}

İz olarak tasarım kategorisi altında imza (2 öğrenci, \%1,1) metaforu ön plana çıkmaktadır. Bu metafora ilişkin öğrenciler "Tasarım imza gibidir, çünkü kişiyi anlatır (Ö72)” ve “Tasarım imza gibidir, çünkü seni ifade eder (Ö89)" ifadeleriyle tasarımın kişiye özgü olduğunu ve kişinin kendisini ifade etmede bir araç olduğunu belirtmişlerdir.

\subsubsection{Kültür Olarak Tasarım}

Kültür olarak tasarım kategorisi altında tek bir öğrenci tarafından tercih edilen kültür (1 ögrenci, \%0,6) metaforu bulunmaktadır. Bu metafora ilişkin öğrenci “Tasarım kültür gibidir, çünkü geçmişimizi ve geleceğimizi yansıtır (Ö69) ” ifadesiyle tasarımın geçmişi ve geleceği birleştiren bir işlevi olduğu vurgulamıştır.

\subsubsection{Obje Olarak Tasarım}

Obje olarak tasarım kategorisini 10 öğrenci $(\% 5,6)$ ve 8 metafor temsil etmektedir. Tasarımın objelerle ilişkilendirildiği bu kategoride geliştirilen metaforlar içinde ayna (2 öğrenci, \%1,1) ve mum (2 öğrenci, \%1,1) metaforları ön plana çıkmaktadır. Öğrenciler ayna metaforuna ilişkin "Tasarım ayna gibidir, çünkü yansıtır (Ö159)”, mum metaforuna ilişkin “Tasarım mum gibidir, çünkü ışık saçar (Ö94)” ifadelerini kullanmışlardır. Ayna ve mum metaforları ile tasarımın yansıtma ve yol gösterici özelliğiyle ilişkilendirdikleri düşünülebilir.

\subsubsection{1. Ölçüt Olarak Tasarım}

Ölçüt olarak tasarım kategorisi altında tek bir öğrenci tarafından tercih edilen kusursuz olmak $(1$ öğrenci, \%0,6) metaforu bulunmaktadır. Bu metafora ilişkin öğrenci “Tasarım kusursuz olmak gibidir, çünkü hata kabul etmez (Ö87) ” şeklindeki ifadesiyle tasarımın hata kabul etmeyeceğini ve kusursuz olması gerektiğini ifade etmiştir.

\subsubsection{2. Özgürlük Olarak Tasarım}

Özgürlük kategorisi altında özgürlük (7 öğrenci, \%4,2) ve sınırsızlık (1 öğrenci, \%0,6) metaforları geliştirilmiştir. Özgürlük metaforuna ilişkin öğrenciler "Tasarım özgürlük gibidir, çünkü hayal gücünü istediğin gibi kullanmaktır 
(Ö25)”, “Tasarım özgürlük gibidir, çünkü tel örgüler yoktur (Ö58)” ve sınırsızlık metaforuna ilişkin “Tasarım sınırsızlık gibidir, çünkü kural yoktur (Ö84)” ifadelerini kullanmışlardır. Bu ifadelerle tasarım kavramının özgür ve yaratıcı olması gerektiği, tasarım sürecinde hayal gücünün sınırlarının olmadığı, bir kurala bağlı olmadan yapılması gerektiği vurgulanmıştır.

\subsubsection{Sanat Olarak Tasarım}

Sanat kategorisi altında $5(\% 5,1)$ metafor geliştirilmiştir. Bu metaforlar içinde estetik (2 öğrenci, \%1,1) metaforu ön plana çıkmaktadır. Estetik metaforuna ilişkin öğrenciler "Tasarım estetik gibidir, çünkü en güzelini bulmak isteriz (Ö142)” ve “Tasarım estetik gibidir, çünkü güzeldir (Ö183)” ifadelerini belirtmişlerdir. Tasarımın hayatı güzelleştiren ve estetik bir değer katan özelliğiyle kullanıldığı görülmektedir.

\subsubsection{Yaratıcılık Olarak Tasarım}

Bu kategoriyi 22 öğrenci $(\% 12,4)$ ve $11(\% 16,1)$ metafor temsil etmektedir. Bu kategoride dikkat çeken metaforlar yenilik (7 öğrenci, \%4,0), yaratıcılık (4 öğrenci, \%2,3) ve teknoloji (3 öğrenci, \%1,7) metaforlarıdır. Yenilik metaforuna ilişkin öğrenciler "Tasarım yenilik gibidir, çünkü üretiriz (Ö119)”, “Tasarım yenilik gibidir, çünkü her seferinde yeni bir şeyler ortaya çıkar (Ö140)”, “Tasarım yenilik gibidir, çünkü olmayanı ortaya koyarız (Ö185)" ifadelerini kullanmışlardır. Öğrenciler yaratıcılık metaforuna ilişkin olarak "Tasarım yaratıcılık gibidir, çünkü yeni fikirler ortaya koymaktır (Ö133)", teknoloji metaforuna ilişkin olarak ise "Tasarım teknoloji gibidir, çünkü gün geçtikçe yeni bilgiler verir (Ö133)” ifadelerini kullanmışlardır. Yenilik, yaratıcılık ve teknoloji metaforu gerekçelerine bakıldığında tasarımın özgün olma, yeni fikirler ortaya koyma ve sürekli olarak yenilenme işleviyle ele alındığ görülmektedir.

\subsubsection{Yaşam Olarak Tasarım}

Yaşam olarak tasarım kategorisinde hayat (5 öğrenci, \%3,0) metaforu dikkat çekmektedir. Öğrenciler hayat metaforuna ilişkin “Tasarım hayat gibidir çünkü her gün karşılarız (Ö195)” ve "Tasarım yaşam gibidir çünkü hep bir başlangıçtır (Ö112)" ifadelerini belirtmişlerdir. Öğrencilerin yaşam/hayat metaforuna ilişkin olarak tasarımı hayatın bir parçası olarak gördükleri ve yaşamın tasarımı içerdiği düşüncesinden hareket ettikleri görülmektedir.

\subsubsection{Yer/Mekân Olarak Tasarım}

Bu kategoriyi 12 öğrenci $(\% 6,8)$ ve $7(\% 10,2)$ metafor temsil etmektedir. Bu kategoride ön plana çıan metaforlar; inşaat (4 öğrenci, \%2,3) ve dünya (3 öğrenci, \%1,7) metaforlarıdır. Öğrenciler inșaat metaforuna ilişkin "Tasarım inşaat gibidir, çünkü ne kadar sağlam olursa o kadar kalıcı olur (Ö145)” ve “Tasarım inşaat gibidir, çünkü ne kadar dayanıklı olursa o kadar uzun soluklu olur (Ö155)" ifadelerini belirtmişlerdir. Öğrenciler dünya metaforuna ilişkin “Tasarım dünya gibidir, çünkü döngü içerisindedir (Ö145)" ifadelerini belirtmişlerdir. Gerekçeleri dikkate alındığında tasarım kavramının inşaat kadar sağlam bir yapı ve dünya gibi durağan olmayan, sürekli bir değişim ve dönüşüm halinde olan çevre ile ilişkilendirildiği görülmektedir.

\subsubsection{Zaman Olarak Tasarım}

Zaman olarak tasarım kategorisi altında öğrenciler, süreç (1 öğrenci, \%0,6) ve zaman (3 öğrenci, \%1,7) metaforlarını geliştirmişlerdir. Öğrenciler süreç metaforuna ilişkin "Tasarım süreç gibidir, çünkü aşama aşama ilerleriz (Ö65)", zaman metaforuna ilişkin "Tasarım zaman gibidir, çünkü durăgan değil, de ğişkendir (Ö51)", ifadelerini belirtmişlerdir. Tasarımın bir aşamalı bir süreç içinde olduğu ve tasarımın zaman gibi değişim içinde olma özelliği üzerinde durulmuştur.

\subsection{Bölümlere İlişkin Bulgular}

Kategoriler ile bölümler arasındaki ilişkilere yönelik kay-kare analizi sonuçları Tablo 3’te sunulmuştur.

Tablo 3

Metaforların Bölümlere Göre Dă̆llımı

\begin{tabular}{|c|c|c|c|c|c|c|}
\hline Kategoriler & & Geleneksel Türk Sanatları & Grafik Tasarım & Seramik ve Cam & Resim & Toplam \\
\hline \multirow{2}{*}{ Alan/Tür } & $\mathrm{n}$ & 1 & \multirow{2}{*}{ - } & \multirow{2}{*}{ - } & 4 & 5 \\
\hline & $\%$ & $\% 2,6$ & & & $\% 8,0$ & $\% 2,8$ \\
\hline \multirow{2}{*}{ Amaç } & $\mathrm{n}$ & & \multirow[b]{2}{*}{ - } & 2 & 2 & 4 \\
\hline & $\%$ & - & & $\% 7,1$ & $\% 4,0$ & $\% 2,3$ \\
\hline \multirow{2}{*}{ Bilişsel Süreçler } & $\mathrm{n}$ & 5 & 20 & 2 & 7 & 34 \\
\hline & $\%$ & $\% 13,2$ & $\% 32,8$ & $\% 7,1$ & $\% 14,0$ & $\% 19,2$ \\
\hline \multirow{2}{*}{ Duyuşsal Süreçler } & $\mathrm{n}$ & 2 & 1 & 4 & 2 & 9 \\
\hline & $\%$ & $\% 5,3$ & $\% 1,6$ & $\% 14,3$ & $\% 4,0$ & $\% 5,1$ \\
\hline \multirow{2}{*}{ Duyuşsal ve Bilişsel Süreçler } & $\mathrm{n}$ & & \multirow[b]{2}{*}{ - } & \multirow[t]{2}{*}{ 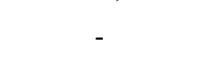 } & 3 & 3 \\
\hline & $\%$ & - & & & $\% 6,0$ & $\% 1,7$ \\
\hline \multirow{2}{*}{ Doğa } & $\mathrm{n}$ & 8 & 8 & 3 & 6 & 25 \\
\hline & $\%$ & $\% 21,1$ & $\% 13,1$ & $\% 10,7$ & $\% 12,0$ & $\% 14,1$ \\
\hline
\end{tabular}


Tablo 3'ün devamı

\begin{tabular}{|c|c|c|c|c|c|c|}
\hline Kategoriler & & Geleneksel Türk Sanatları & Grafik Tasarım & Seramik ve Cam & Resim & Toplam \\
\hline \multirow{2}{*}{ İnsana özgü } & $\mathrm{n}$ & 6 & 8 & 3 & 4 & 21 \\
\hline & $\%$ & $\% 15,8$ & $\% 13,1$ & $\% 10,7$ & $\% 8,0$ & $\% 11,9$ \\
\hline \multirow{2}{*}{$\dot{I ̇ z}$} & $\mathrm{n}$ & 1 & 3 & - & & 4 \\
\hline & $\%$ & $\% 2,6$ & $\% 4,9$ & - & - & $\% 2,3$ \\
\hline \multirow{2}{*}{ Kültür } & $\mathrm{n}$ & & 1 & & & 1 \\
\hline & $\%$ & - & $\% 1,6$ & - & - & $\% 0,6$ \\
\hline \multirow{2}{*}{ Obje } & $\mathrm{n}$ & 2 & 3 & 4 & 1 & 10 \\
\hline & $\%$ & $\% 5,3$ & $\% 4,9$ & $\% 14,3$ & $\% 2,0$ & $\% 5,6$ \\
\hline \multirow{2}{*}{ Ölçüt } & $\mathrm{n}$ & 1 & & , & 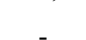 & 1 \\
\hline & $\%$ & $\% 2,6$ & - & - & - & $\% 0,6$ \\
\hline \multirow{2}{*}{ Özgürlük } & $\mathrm{n}$ & 3 & 4 & & 1 & 8 \\
\hline & $\%$ & $\% 7,9$ & $\% 6,6$ & - & $\% 2,0$ & $\% 4,5$ \\
\hline \multirow{2}{*}{ Sanat } & $\mathrm{n}$ & 2 & 1 & 1 & 2 & 6 \\
\hline & $\%$ & $\% 5,3$ & $\% 1,6$ & $\% 3,6$ & $\% 4,0$ & $\% 3,4$ \\
\hline \multirow{2}{*}{ Yaratıcılık } & $\mathrm{n}$ & 4 & 4 & 6 & 8 & 22 \\
\hline & $\%$ & $\% 10,5$ & $\% 6,6$ & $\% 21,4$ & $\% 16,0$ & $\% 12,4$ \\
\hline \multirow{2}{*}{ Yaşam } & $\mathrm{n}$ & 1 & 3 & 1 & 3 & 8 \\
\hline & $\%$ & $\% 2,6$ & $\% 4,9$ & $\% 3,6$ & $\% 6,0$ & $\% 4,5$ \\
\hline Yer/ & $\mathrm{n}$ & 2 & 2 & 1 & 7 & 12 \\
\hline Mekân & $\%$ & $\% 5,3$ & $\% 3,3$ & $\% 3,6$ & $\% 14,0$ & $\% 6,8$ \\
\hline \multirow{2}{*}{ Zaman } & $\mathrm{n}$ & & 3 & 1 & & 4 \\
\hline & $\%$ & - & $\% 4,9$ & $\% 3,6$ & - & $\% 2,3$ \\
\hline \multirow{2}{*}{\multicolumn{2}{|c|}{ Toplam }} & 38 & 61 & 28 & 50 & 177 \\
\hline & & $\% 100$ & $\% 100$ & $\% 100$ & $\% 100$ & $\% 100$ \\
\hline
\end{tabular}

*Beklenen frekansı 5 'in altına düşen hücre sayısı ( $n=57)$ toplam hücrelerin yaklaşık\%83,8'ini oluşturduğu için bu analizde anlamlılık yorumu yapılmamış sadece çapraz tablo kullanılmıştır.

Tablo 3'e göre öğrencilerin tasarım kavramına ilişkin oluşturdukları metaforların bölümlere göre farklılık gösterdiği görülmektedir. Geleneksel Türk Sanatları Bölümü öğrencileri en çok doğa (8 öğrenci, \%21,1), insana özgü (6 öğrenci, \%15,8) ve bilişsel süreçler (5 öğrenci, \%13,2) kategorisine ait metaforlar geliştirmişlerdir.

Grafik Tasarım Bölümü öğrencileri bilişsel süreçler (20 öğrenci, \%32,8), doğa (8 öğrenci, \%13,1) ve insana özgü (8 öğrenci, \%13,1) kategorilerinin altında yer alan metaforlar üretmiş̧lerdir.

Geleneksel Türk Sanatları ve Grafik Tasarım Bölümü öğrencilerinin tasarım kavramını doğa, insan ve bilişsel süreçlerle ilişkilendirdikleri söylenebilir.

Seramik ve Cam Bölümü öğrencilerinin geliştirdikleri metaforlar incelendiğinde yaratıcılık (6 öğrenci, \%21,4), obje (4 öğrenci, \%14,3) ve duyuşsal süreçler (6 öğrenci, \%14,3) kategorileri dikkat çekmektedir.

Resim Bölümü öğrencilerinin geliştirdikleri metaforlar incelendiğinde ise bilişsel süreçler (7 öğrenci, \%14,0), doğa (6 öğrenci, \%12,0), yaratıcılık (8 öğrenci, \%16,0) ve yer/mekân (7öğrenci, \%14,0) kategorileri ön plana çıkmaktadır.

Tüm bölümler tarafından ortak olarak en çok tercih edilen kategoriler sırasıyla; bilişsel süreçler olarak tasarım (34 öğrenci, \%19,2), doğa olarak tasarım (25 öğrenci, \%14,1), yaratıcılık olarak tasarım (22 öğrenci, \%12,4) ve insana özgü olarak tasarım (21 öğrenci, \%11,9) şeklinde sıralanabilir.

\section{Sonuç ve Öneriler}

Güzel Sanatlar ve Tasarım Fakültesi öğrencilerinin tasarım kavramına yönelik metaforlarının belirlendiği bu çalışmada öğrencilerin geliştirdikleri zihinsel imgelerin geniş ölçekte farklı metaforlara işaret ettiği görülmüştür. Yob (2003)'a göre herhangi bir konuda yapılan metafor çalışmalarında metafor verilerinin çeşitli olması önemlidir. $\mathrm{Bu}$ açıdan bu araştırmada tasarım kavramına yönelik 98 metafor ve 17 kategorinin tespit edilmesi önemli bir sonuç olarak görülmektedir.

Araştırmanın kavramsal kategorilerine ilişkin olarak Akdeniz ve Çarıkçı'nın (2017) yapmış olduğu "sanat eğitimi" kavramına ilişkin araştırma bulguları bu çalışma ile paralellik göstermektedir. Akdeniz ve Çarıkçı (2017) yapmış olduğu araştırmada sanat eğitimi metaforlarını; temel ihtiyaç olması, yaratıcılığı desteklemesi, çaba gerektirmesi, hayatın bir parçası olması, kişisel gelişim ve öğrenmeyi desteklemesi ve duyguların ifadesi olması yönüyle 5 kategori altında toplamışlardır. Akdeniz ve Çarıkçı'nın (2017) sanat eğitimine ilişkin tespit etmiş oldukları "yaratıcılığı desteklemesi, hayatın bir parçası olması ve duyguların ifadesi" kategorileri bu araştırmada ortaya çıkarılan yaratıcılık olarak tasarım, hayat/yaşam olarak tasarım ve duyuşsal olarak tasarım kategorileriyle örtüşmektedir.

Araştırma bulgularına göre; tasarıma yönelik geliştirilen metafor kategorilerinden bilişsel süreçler olarak tasarım (34 öğrenci, \%19,2), doğa olarak tasarım (25 öğrenci, \%14,1), yaratıc1lı olarak tasarım (22 öğrenci, \%12,4) ve 
insana özgü olarak tasarım (21 öğrenci, \%11,9) kategorilerinin ön plana çıktığı görülmektedir. Güzel Sanatlar ve Tasarım Fakültesi öğrencilerinin tasarım kavramını zihinsel bir süreç olarak algıladığı, doğa ve yaratıcılık ile ilişkilendirerek, insana özgü anlamlar yüklediği tespit edilmiştir.

Araştırmada elde edilen veriler doğrultusunda öğrenciler tarafından geliştirilen metaforlar kategoriler bakımından incelendiğinde bölümlere göre farklılık göstermektedir. Geleneksel Türk Sanatları öğrencileri 13 kategoride metafor üretmiş, özellikle doğa (8 öğrenci, \%21,1) ve insana özgü (6 öğrenci, \%15,8) kategorilerinde yoğun olarak metafor geliştirmişlerdir. Geleneksel Türk Sanatı öğrencilerinin tasarım kavramını doğa ve insana özgü unsurlarla açıkladıkları görülmektedir.

Grafik Tasarım Bölümü öğrencileri de 13 kategoride metafor üretmiştir ve özellikle bilişsel süreçler (20 öğrenci, \%32,8) kategorisinde yoğunlaştıkları görülmektedir. Grafik Tasarım Bölümü öğrencileri tasarım kavramını zihinsel bir süreç olarak görmektedir. Seramik ve Cam Bölümü öğrencilerinin 10 kategoride metafor geliştirdikleri görülmüş ve yaratıcılık (6 öğrenci, \%21,4) kategorisinde yoğunlaştıkları tespit edilmiştir. Seramik ve Cam Bölümü öğrencileri, tasarımı yaratıcı bir süreç olarak görmektedir. Resim Bölümü öğrencileri ise 13 farklı kategoride metafor üretmiş olup bilişsel süreçler (7 öğrenci, \%14,0), doğa (6 öğrenci, \%12,0), yaratıcılık (8 öğrenci, \%16,0), yer/zaman (7 öğrenci, \%14,0) kategorilerinde yoğunlaşmışlardır. Resim Bölümü öğrencileri ise tasarım kavramını zihinsel ve yaratıcı bir süreç olarak görmekte, doğa, yer ve zaman kavramları ilişkilendirmektedir.

Dört bölümden farklı olarak Grafik Tasarım Bölümü öğrencileri kültür (1 öğrenci, \%0,6) kategorisinde, Geleneksel Türk Sanatları Bölümü öğrencileri ise ölçüt (1 öğrenci, \%0,6) kategorisinde birer metafor üretmiştir. Buradan Grafik Tasarım Bölümü öğrencilerinin kültür metaforu ile tasarım kavramını geçmiş ve gelecek arasında bağ kurma işleviyle ön plana çıkardığı görülmektedir. Geleneksel Türk Sanatları öğrencilerinin ise ölçüt kategorisi ile tasarımı hatasız ve kusursuz olmak metaforu ile bağdaştırdığı tespit edilmiştir. Bu sonuç, Grafik Tasarım öğrencilerinin tasarımı kültür oluşturmada bir parça olarak gördükleri, Geleneksel Türk Sanatları öğrencilerinin ise tasarımın kusursuz ve ölçüt olması ile ilişkilendirerek diğer bölüm öğrencilerinden farklı metaforlar ürettikleri sonucuna ulaşılmıştır.

Çalışmanın sonuçlarından ziyade araştırmacının gözlemleri dikkate alındığında; tasarım metaforu hakkında öğrencilerin fikirlerine başvurulması öğrencilerin kendilerini değerli hissetmelerini sağlamış ve bu durum öğrencilere özgüven kazandırmıştır.

Güzel Sanatlar ve Tasarım Fakültelerinde alana ilişkin farklı konularda yapılacak metafor çalışmaları öğrencilerin alanlarına ilişkin farklı bir bakış açısı kazanmalarını sağlayacaktır. Ayrıca metaforların bilgileri hatırlamada ve yeni bilgilerin öğrenilmesinde sağladığı katkı düşünüldüğünde, metafor çalışmalarının yapılması önerilmektedir.

\section{Kaynakça}

Akdeniz, A., \& Çarıkçı, E. (2017). Konservatuar öğrencilerinin sanat eğitimi kavramına ilişkin metaforik algıları. Mustafa Kemal Üniversitesi Sosyal Bilimler Enstitüsü Dergisi, 40(14). 59-85. https://dergipark.org.tr/tr/ download/article-file/394615

Baş, T., \& Akturan, U. (2008). Nitel araştırma yöntemler Nvivo 7.0 ile nitel veri analizi. Seçkin Yayıncılık.

Becer, E. (2009). Iletişim ve grafik tasarım (7. Bask1). Dost Kitabevi Yayınları.

Büyüköztürk, Ş., Kılıç Çakmak, E., Akgün, Ö.E., Karadeniz, Ş., \& Demirel, F. (2017). Bilimsel araştırma yöntemleri (23 Basım). Pegem Yayıncılık.

Çaydere, O. (2016). Tasarımdan çağdaş tasarıma. NWSA Fine Arts. 11(1), 46-53. http://dx.doi.org/10.12739/ NWSA.2016.11.1.D0172

Çevik, S. (2011). Grafikerin köşe taşı (1. basım). Marjinal Kitap.

Miles, M. A., \& Huberman, S. M. (2019). Nitel veri analizi. (S. Akbaba Akgül ve A. Ersoy, Çev.). Pegem Yayıncilik.

Patton, M. Q. (2018). Nitel analiz ve yorumlama. S. B. Demir (Çev. ve Ed.), Nitel araştırma ve değerlendirme yöntemleri (s.429-540) içinde. Pegem Yayıncılık.

Saban, A., Koçbeker, B. N., \& Saban, A. (2006). Öğretmen adaylarının öğretmen kavramına ilişkin algılarının metafor analizi yoluyla incelenmesi. Kuram ve Uygulamada Eğitim Bilimleri, 6(2), 509-522. https://app.trdizin.gov.tr/makale/T0RNeE9USXk

Şentuna Akay, E. (2019). İçerik analizine giriş. A. Arı (Çev. ve Ed.), Sosyal bilimlerde nitel araştırma yöntemleri (s. 343-375) içinde. Dizgi Yayıncılık. https://books.google.com.tr/books 
Tanrıverdi, H., \& Kahraman, C. (2019). Metafor Analizi. Ş. Aslan (Ed.), Sosyal bilimlerde araştırma yöntemleri nitel, nicel ve karma tasarımlar için bir rehber (s.275-286) içinde. Eğitim Yayınları. https://books.google.com.tr/books

TDK. (t.y). Tasarım. Türk Dil Kurumu güncel Türkçe sözlük içinde. https://sozluk.gov.tr.

Uçar, M., Canbolat, C., \& İlhan, S. (2019). Güzel Sanatlar ve Tasarım Fakültesi Öğrencilerinin Sanat Kavramına İlişkin Zihinsel İmgeleri. Sanat ve Tasarım, 23, 393-411. https://dergipark.org.tr/tr/download/article$\underline{\text { file } / 737550}$

Yıldırım, A., \& Şimşek, H. (2018). Sosyal bilimlerde nitel araştırma yöntemleri (11. Baskı). Pegem Yayıncılık.

Yob, I. M. (2003). Thinking constructively with metaphors. Studies in Philosophy and Education, 22, 127-138. https://doi.org/10.1023/A:1022289113443 